\title{
The Influence of Physical Activity on Functional Performance and Urinary Incontinence in Elderly Women
}

\author{
C.M. Magaldi $^{1} \quad$ A. Saraiva ${ }^{2} \quad$ P.M. Franciulli ${ }^{1} \quad$ F.M. Magaldi ${ }^{1} \quad$ M. Moreno ${ }^{1} \quad$ M.L.J. Miranda ${ }^{3}$ \\ L.B.M. Maifrino ${ }^{4}$
}

1 Universidade São Judas Tadeu, São Paulo, SP, Brasil

${ }^{2}$ Instituto de Ciências da Saúde, Universidade Federal da Bahia,

Salvador, BA, Brasil

3 Programa de Pós-graduação Stricto Sensu em Educação Física, Universidade São Judas Tadeu, São Paulo, SP, Brasil

4 Programa de Pós-graduação Stricto Sensu em Educação Física, Instituto Dante Pazzanese de Cardiologia, Universidade São Judas

Tadeu, São Paulo, SP, Brasil

\begin{abstract}
Address for correspondence C.M. Magaldi, Universidade São Judas Tadeu - USJT, Rua Taquari, 546, Mooca, CEP 03166-000, São Paulo, SP, Brazil (e-mail: magaldi.fisio@gmail.com).
\end{abstract}

J Morphol Sci 2018;35:1-8.

\begin{abstract}
Introduction Urinary incontinence (UI) is the involuntary urine loss, with the prevalence of $17 \%$ to $24 \%$ in women over 65 years-old. It has a multifactorial cause, being a condition that affects many people in all ages mainly postmenopausal women, it is also found in athlete women who have a high level of training associated mainly to high impact activities.

Objective The aim of this study is to conduct a literature review that relates the influence of physical activity on functional performance and on UI among women on the stage of aging.

Keywords

- physical activity

- exercises

- urinary incontinence

- aging

Method The bibliographical review was done in Medline, Scielo, Pubmed and SportsDisco databases using the keywords physical activity or exercise, postmenopause or aging and urinary incontinence and stress urinary incontinence.

Conclusion Elderly women engaged in a regular exercise program have a lower incidence of UI.
\end{abstract}

\section{Introduction}

The growth of aging population has now become a universal phenomenon, concerning to developed and under developing countries alike.

The participation in the regular physical activity (aerobic and anaerobic exercises) provides positive responses to healthy aging. The physical inactivity can be perceived as a major public health problem, as being active drives down the locomotive system limitations, promotes the maintenance of physical capacity and the autonomy of the elderly Silva et al. ${ }^{1}$
With the increasing life expectancy, it is needed to know the amplitude and mechanisms of how physical exercises can improve the health, functional ability, quality of life and independence among this population.

The regular physical activity aim is to improve cardiorespiratory, muscular, skeletal systems, and to reduce the risk of non- communicable diseases. It is recommended that adults from 18 to 64 years old should perform at least 150 minutes of moderate intensity physical activity per week. ${ }^{2}$ As per Ciolac, ${ }^{3}$ the aging process cannot be avoided and a sedentary life might accelerate this process, increasing received

November 12, 2017

accepted

March 9, 2018
DOI https://doi.org/

10.1055/s-0038-1660498. ISSN 2177-0298.
Copyright $(2018$ by Thieme Revinter

Publicações Ltda, Rio de Janeiro, Brazil
License terms

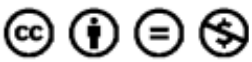


the occurrence of chronic diseases. Moreover, the regular physical activity practice improves the quality of life and increases life expectancy.

The urinary incontinence (UI) is a frequent complain among women, it can range from $32 \%$ and $64 \%$. The most common type is the stress urinary incontinence (SUI) characterized by involuntary urine loss on physical exertion or exercising, reflecting on her daily routine, professional and sports activities Abrams et al. ${ }^{4}$ Several factors might influence this condition, as age, medication (diuretics and $\alpha$-blockers), endocrine dysfunctions (diabetes), central or peripheral neuropathy (multiple sclerosis), prolapse, pelvic floor denervation, obesity and smoking. ${ }^{5}$ The urinary symptoms are also present in the transition from perimenopause to postmenopause. The urinary tract trophic changes caused by hypoestrogenism increases the susceptibility to infections, bladder filling disorders, dysuria, vaginal dryness, and dyspareunia. The atrophy of urinary tract tissues can also increase the incidence of $U I$ by the presence of estrogen receptors and the common embryology of the bladder, urethra, and vagina influencing the onset of UI symptoms after menopause. $^{5}$

The UI leads to occupational, domestic and sexual activities restrictions, causing discomfort that includes needing constantly panty liners to prevent urine leakage, frequent changing of clothing, the odor of urine and skin rashes, affecting negatively the quality of life. ${ }^{6}$

\section{Functional and morphological aspects of the urinary bladder}

There are functional differences among the several parts of the bladder. The ureterovesical junction (UVJ) is the name that is assigned to the transition zone between the bladder and the urethra, and it has an important role in the urine storage and voiding. Such function is maintained by a synergistic process that engages central and autonomic nervous systems, detrusor muscle and urethral sphincter. ${ }^{7,8}$

The urine storage occurs under low pressure, so bladder relaxes during the filling stage. Disorders in the storage functions can lead to lower urinary tract symptoms (LUTS), such as urgency, frequency and urge incontinence, caused by contraction of the smooth muscle of bladder on this stage. The emptying requires coordination between bladder contraction and urethra relaxation. Disorders in the emptying stage can lead to voiding dysfunctions such as incomplete emptying of the bladder sensation on post voiding. The LUTS rises significantly with age, irrespectively of whether they are men or women, is a major problem for the elderly. ${ }^{9}$

The urinary bladder stores adequate volume of urine, allowing the accumulation of volumes without increasing the intravesical pressure. Its muscle fibers spread in every direction and once the intravesical pressure increases, the emptying happens through the contraction of smooth muscle (detrusor muscle) and the relaxation of striated muscle from external urethral sphincter, to allow the urination to occur.

The bladder wall is composed of three layers: the innermost layer, the mucosa, which contains transitional epithelium tissue and is impermeable to urine; middle layer, muscular, the most developed one and which made bladder to be known as a dense muscular organ; and the outermost layer, adventitia, composed of connective tissue since serosa is just found in the upper region of the bladder. ${ }^{10}$ The muscular layer (detrusor muscle) consists in a central region of fibers arranged in a circular configuration containing 3 irregularly arranged layers of smooth muscle, intermixed with collagen fibers which makes difficult to distinguish the internal, circular and external layers of the detrusor muscle. The contraction of this muscular layer is related to urination reflex, as the muscle stretches out when the bladder is filled with urine, and this condition affects the autonomic innervation, that is under voluntary control. Thus, parasympathetic nervous system fibers are responsible for urination reflex, they are located amongst the muscular fibers layers and are responsible for bladder contraction. The sympathetic nervous system fibers are responsible for bladder relaxation and compose a plexus on the adventitia, innervating the blood vessels. $^{9}$

The cells of external and internal layers tend to be arranged longitudinally and the ones from middle layer circularly. The configuration of these fibers helps the tissue architecture, enables a passive action on the tissue when under mechanical stretch, facilitating to return to the original position; along with collagen cells, the elastin cells are important for the maintenance of a regular tissue resistance. ${ }^{9}$

There is a high intercellular cohesion level that protects the bladder against the excessive volume. The collagen concentration on the vesical wall is closely related to the protection level available. The smooth muscle cells of the bladder help the collagen production accordingly to the bladder wall distension triggers. ${ }^{11}$

The smooth muscles exhibit an extreme variability, not only in ultrastructural details, but also in their contractile, regulatory, and electrophysiological properties and in their sensitivities to drugs and neurotransmitters. ${ }^{9}$

\section{The bladder extracellular matrix}

The cells of a tissue are generally attached to a complex extracellular macromolecules network known as extracellular matrix (ECM) that sets cells and tissues together, providing an organized structure where cells can migrate and interact with each other and also support most of the mechanical stress the tissue is exposed to.

The extracellular matrix (ECM) molecules are composed of two main classes of macromolecules: glycosaminoglycans (GAGs) and proteins. The ECM protein components are also classified in structural such as collagen and elastin and adhesive as fibronectin and laminin. ${ }^{12,13}$

The bladder ECM is composed of proteins, proteoglycans and GAGs that provides support to bladder cells and components, playing an important role in protecting the urothelium and in urine storage. The GAGs protective membrane (main chondroitin) that covers the urothelial cells form a barrier against several toxic substances. ${ }^{14}$

Most of the bladder collagen is found in the connective tissue outside the muscle bundles, in the perimysium. The main types of collagen found in the bladder are: collagen type I that represents $\sim 75 \%$ of the bladder collagen, they are 
disposed in wavy shape and under volumetric load they stretch and can become 3\% to 5\% longer; and collagen type III that represents $\sim 25 \%$ of the bladder collagen, usually found around type I collagen, widely distributed throughout the vesical wall. Collagen type II seems to undergo conformational changes to adjust to the intravesical volume. ${ }^{15}$

During regular aging occurs elastic fibers fragmentation, a decrease in smooth muscle cells, disarrangement and broadening of collagen and increase of amorphous ground substance, causing the reduction of elastic properties in the urinary bladder. ${ }^{16}$

\section{Aging and urinary incontinence}

The UI is a usual issue on women aging, with prevalence of $17 \%$ to $24 \%$ in women over 65 years-old, and increase $~ 75 \%$ in women above 75 years-old. ${ }^{17}$

Based on epidemiological studies, the occurrence of UI in elderly women is related to diabetes, hypertension, and obesity. $^{18}$

The correlation between the estrogen serum levels and the urogenital system atrophy is directly related to the incidence of UI. However, as there is a clear relationship between the higher prevalence of UI and age, so it is a huge challenge to establish whether the prevalence is due to the estrogen decrease in menopause or part of the regular aging process. ${ }^{19}$

Morphological, structural and histological studies over the urinary bladder found weight increase, thickening of the bladder wall, thinning of the urothelial layer, reduction of muscle mass and increase in collagen quantity and, therefore, disorders in the bladder storage and filling processes. ${ }^{20}$ Kitta et al. $^{21}$ analyzed how the ovariectomy in middle age and young adult female rats affects the urinary continence mechanism during sneeze reflex and noticed apoptotic changes in the urethral tissue. Hence, aging and estrogen deficiency affect baseline urethral function and can induce SUI in postmenopause women.

Several factors can be the reason behind the filling disorders observed during aging, including detrusor muscle fibrosis, and therefore, vesical contraction limitation, collagen deposition, and accumulation. During aging process, the smooth detrusor muscle progressively develops fibrosis by collagen deposition and may change the vesical contractility, resulting in involuntary vesical contractions. ${ }^{22}$

The aging is also related to the reduction of urethral sphincter function in a woman, a reduction on striated muscle cells in rhabdosphincter of humans and an increase on urethral muscle fibers apoptosis. ${ }^{23}$

The dysfunctions on the pelvic floor muscle (PFM) are frequent and bring uncomfortable problems including several conditions that affect the performance of daily activities, sports, sexual and social activities, having consequences as urinary and fecal incontinence, lower urinary tract abnormalities, sexual dysfunctions, pelvic pain and pelvic organs prolapses.

The aging is a well-known factor that affects the PFM and lower urinary tract function due to hormonal deficiency, is likely one of the causes of pelvic floor muscle dysfunctions on elderly women, that can lead to pelvic organs prolapse and $\mathrm{UI}^{24,25}$
The levator ani and the coccygeus muscle are connected to the pelvis inner surface and along with the urogenital diaphragm muscles compose the pelvic floor muscles (PFM). The levator ani consists of three main muscles: the pubococcygeus, the puborectalis and the iliococcygeus. ${ }^{26}$ The pubococcygeus and the puborectalis muscles have a $U$ shape and arise from pubic bone through both sides of midline and stretches behind the anus. They are formed mainly by striated muscular fibers type I, which are important to maintain continuous tone during resting state and keep the urogenital hiatus closed. The iliococcygeus arises laterally from tendinous arch reaching the gap on the posterior part of the pelvis, providing thereby support to the pelvic organs. $^{27}$

The PFMs are functionally essential to maintain continence and pelvic support. Ultrasonography studies shows that under the sudden rise of intra abdominal pressure (around $150 \mathrm{cmH}_{2} \mathrm{O}$ ) the proximal urethra undergoes a displacement of the midsagittal plane close to $10 \mathrm{~mm}$, therefore the lower abdominal content is forced caudodorsally, due to a simultaneous contraction of the diaphragm and the abdominal wall muscles. The bladder neck downward move that is visible on the ultrasonography makes the surrounding tissues to move downwards. The abdominal pressure is transversally transferred to the urethra, so that its anterior wall is deformed toward the posterior, thereby helping to close the urethral lumen and prevent urine loss caused by increased intravesical pressure. The PFMs injury reduces the support layer and provides less resistance against deformity while increased abdominal pressure, thus the urethral lumen closing is ineffective, increasing the incidence of SUI. ${ }^{27}$

The muscles in elderly have around 35\% less strength, exhibit mass loss and atrophy mainly in type II fibers, when compared with a young adult. ${ }^{28}$ These changes are not due to neural recruitment but to aging on muscle contractility. Furthermore, if PFMs are damaged or the innervation is impaired, muscle contraction will take even longer to make the same strength. ${ }^{27,28}$

The presence of estrogen receptors in the pelvic floor muscles means that the reduction of this hormone concentration in the body can also promote changes in this musculature. 25,29

Bocardi et al. ${ }^{30}$ after observing the aging effect over PFM function and electromyographic activity in healthy and nulliparous women from 18 to 69 years old, noticed no difference among the several groups of different ages when comparing the pelvic floor function and muscular strength. However, a low negative correlation was found between age and the electromyographic activity of the pelvic floor muscles revealing the trend that higher the age, lower the electromyographic activity of these muscles.

The pelvic floor is directly related to the urinary continence mechanism, as the muscular function is better on physically active women. ${ }^{31}$ Women that have UI usually exhibit pelvic floor dysfunctions. Strengthening these muscles results in an efficient improvement in urinary losses. ${ }^{32}$ 
Table 1 Complete database research strategy

\begin{tabular}{|l|l|}
\hline Keywords in English & Keywords in Portuguese \\
\hline $\begin{array}{l}\text { Physical activity OR exercises AND postmenpausal OR elderly } \\
\text { OR aged OR older AND urinary incontinence }\end{array}$ & $\begin{array}{l}\text { Atividade física OR exercícios AND pós-menopausa OR } \\
\text { mulheres idosas OR envelhecimento AND incontinência urinária }\end{array}$ \\
\hline $\begin{array}{l}\text { Physical activity OR exercises AND postmenpausal OR elderly } \\
\text { OR aged OR older AND stress urinary incontinence }\end{array}$ & $\begin{array}{l}\text { Atividade física OR exercícios AND pós-menopausa OR } \\
\text { mulheres idosas OR envelhecimento AND incontinência } \\
\text { urinária de esforço }\end{array}$ \\
\hline
\end{tabular}

\section{Method}

A systematic bibliographical review that examined the influence of physical activity on functional performance and on urinary incontinence among elderly women. The research was performed by 2 (two) editors on articles from January 2000 to January 2017. This study follows platform PRISMA8 protocols over articles selection and eligibility criteria.

The research was done on the following databases: Medline, Sports Disco, Pubmed, and Scielo. In each database, these keywords were checked: urinary incontinence, postmenopause, aging, physical activity, exercise, sport and fitness in Portuguese and its corresponding term in English, with the Boolean operator AND. A manual search was also conducted in all references mentioned in the articles selected for this study. The complete PubMed database research strategy can be found in - Table 1: The eligibility criteria were: aging women population, who performed a regular physical activity for more than three months, there was no initial restriction regarding publications quality. The shortlisted articles were fully analyzed (-Fig. 1).

From the review of titles and abstracts, it was selected for fully reading the cross-sectional and longitudinal randomized clinical trials, which includes a method for assessing incontinence and/or functional performance, type of physical activity performed and incidence of UI.

It was excluded repeated studies, protocols of articles recorded in databases, studies involving pharmacological agents, noninterventional studies or those which didn't specify the type of intervention performed.

\section{Results}

The electronic search identified 218 articles on Medline, Sports Disco, Pubmed and Scielo databases, after removing the duplicates.

After reading the titles, 206 articles were excluded for they were not related to the subject or for being unavailable.

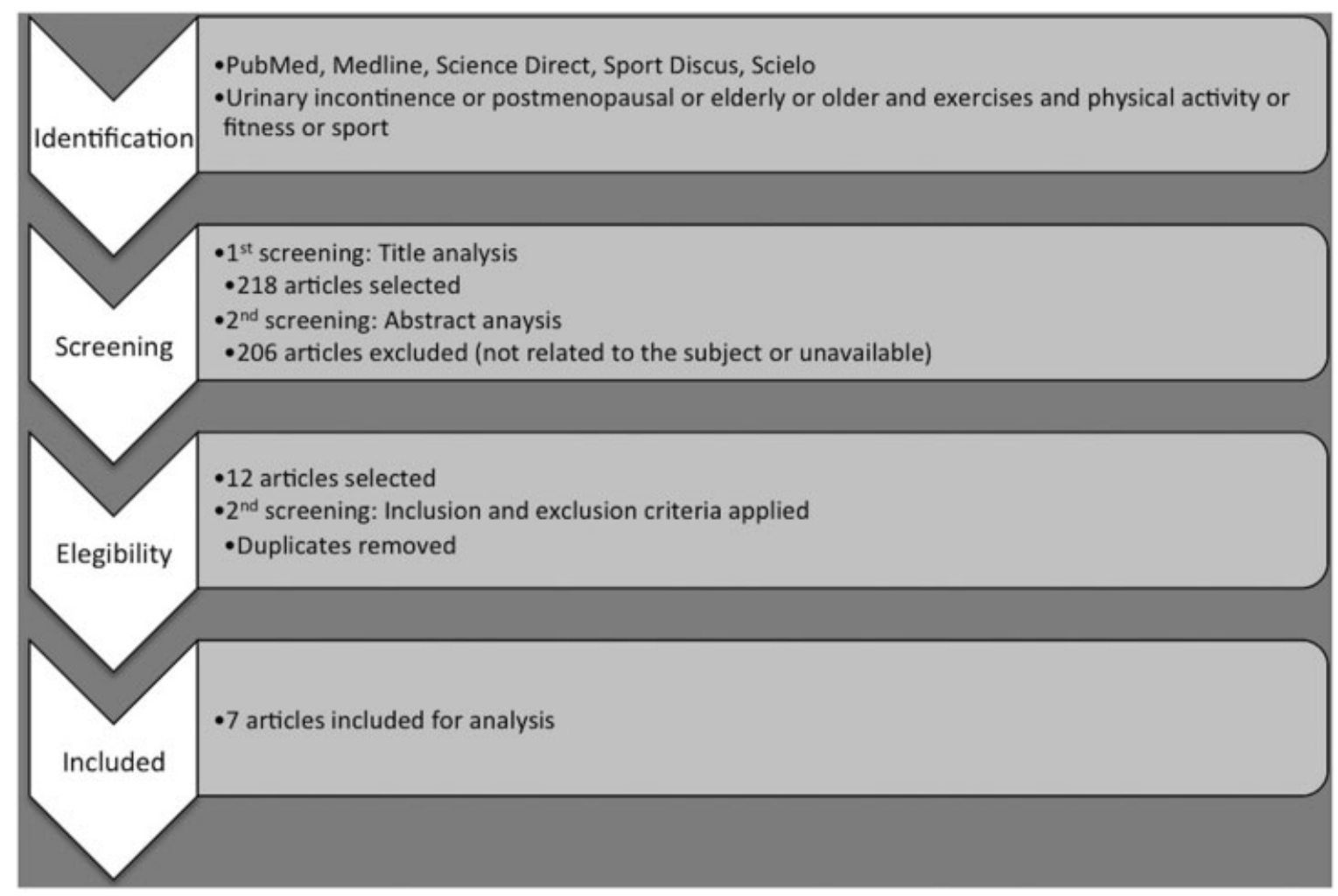

Fig. 1 Studies selection process flowchart, as per PRISMA check-list. 
Table 2 Summary of included studies $(n=8)$

\begin{tabular}{|c|c|c|c|c|c|c|}
\hline Author, year & Type & Age & $\mathrm{N}$ & $\begin{array}{l}\text { Population } \\
\text { characteristics / } \\
\text { intervention }\end{array}$ & Assessment method & Results \\
\hline $\begin{array}{l}\text { Moreno-Vecino } \\
\text { et al. }{ }^{33}(2015)\end{array}$ & Transversal & $>65$ years-old & 471 & Walking & $\begin{array}{l}{\mathrm{ICIQ}-S F^{* *}}^{* *} \text { Fitness } \\
\text { assessment }\end{array}$ & $\begin{array}{l}\uparrow U \text { Ul sedentary group } \\
(p=0,08) \text {. } \\
\downarrow \text { UI walking group } \\
(p<0,01) \\
\uparrow U I \text { smaller the } \\
\text { flexibility }(p<0,01)\end{array}$ \\
\hline $\begin{array}{l}\text { Morrisroe } \\
\text { et al. }{ }^{35}(2014)\end{array}$ & Transversal & 60-93 years-old & 248 & $\begin{array}{l}20 \text { minutes exercising } \\
3 \mathrm{X} \text { per week }\end{array}$ & $\begin{array}{l}\mathrm{ICIQ}^{*} \text { Pedometer and } \\
\text { physical performance }\end{array}$ & $\begin{array}{l}\uparrow \text { functional perfor- } \\
\text { mance } \downarrow \text { Ul symptoms } \\
(p<0,05)\end{array}$ \\
\hline $\begin{array}{l}\text { Tak et al. }{ }^{48} \\
(2012)\end{array}$ & $\begin{array}{l}\text { Randomized } \\
\text { Controled } \\
\text { Multicentric }\end{array}$ & $\begin{array}{l}\text { Average of } \\
84 \text { years-old }\end{array}$ & $\begin{array}{l}155 \\
85 \text { intervention } \\
\text { and } 70 \text { control }\end{array}$ & $\begin{array}{l}\text { Group exercising on } \\
\text { functional ability to } \\
\text { use the toilet } \\
\text { Pelvic floor training }\end{array}$ & $\begin{array}{l}\text { Physical performance } \\
\text { questionnaire } \\
\text { Three-day voiding } \\
\text { diary }\end{array}$ & $\begin{array}{l}\uparrow \text { functional perfor- } \\
\text { mance has not been } \\
\text { associated to the } \downarrow \text { of } \\
\text { UI }(p>0,01)\end{array}$ \\
\hline $\begin{array}{l}\text { Vinsnes et al. }{ }^{39} \\
(2012)\end{array}$ & $\begin{array}{l}\text { Randomized } \\
\text { Controled } \\
\text { Multicentric }\end{array}$ & $\begin{array}{l}>65 \text { years-old, } \\
\text { average of } \\
84,3 \text { years-old }\end{array}$ & $\begin{array}{l}68 \\
(\mathrm{TG} n=35 / \\
\text { CG } n=33)\end{array}$ & $\begin{array}{l}\text { TG: transfer, walk } \\
\text { ability, balance, } \\
\text { muscle strength, } \\
\text { endurance and ADL } \\
\text { training } \\
\text { CG - habitual care }\end{array}$ & 24 hours Pad-Test & $\downarrow$ UI on TG $(p=0,03)$ \\
\hline $\begin{array}{l}\text { Virtuoso et al. }{ }^{31} \\
(2011)\end{array}$ & Transversal & $>60$ years-old & $\begin{array}{l}28 \text { active } \\
\text { on physical } \\
\text { activities } \\
11 \text { inactive }\end{array}$ & $\begin{array}{l}\text { Exercising the last } 6 \\
\text { months }\end{array}$ & $\mathrm{ICIQ}^{*}$ & $\begin{array}{l}\uparrow U I \text { in women who } \\
\text { performs physical } \\
\text { exercises }(p=0,288)\end{array}$ \\
\hline $\begin{array}{l}\text { Townsend et al. }{ }^{51} \\
(2008)\end{array}$ & $\begin{array}{l}\text { Prospective } \\
\text { cohort }\end{array}$ & $\begin{array}{l}37-54 \text { years-old } \\
\text { (average of } 45,9 \text { ) }\end{array}$ & - & $\begin{array}{l}\text { Walking (35\%), } \\
\text { vigorous activities } \\
\text { (18\%) e calisthenic } \\
\text { exercises }(15 \%)\end{array}$ & $\mathrm{ICIQ}^{*}$ & $\begin{array}{l}\uparrow p h y s i c a l \text { exercises } \\
\downarrow \text { UI }\end{array}$ \\
\hline $\begin{array}{l}\text { Danforth et al. }{ }^{34} \\
(2007)\end{array}$ & $\begin{array}{l}\text { Prospective } \\
\text { cohort }\end{array}$ & $\begin{array}{l}\text { 54-79 years-old } \\
\text { (average of } 65,9 \text { ) }\end{array}$ & 2355 & Walking (> 50\%) & $\mathrm{ICIQ} *$ & $\begin{array}{l}\text { walking } \downarrow \text { UI } 26 \% \\
\uparrow \text { physical exercises } \\
\downarrow \text { UI }(p<0,01)\end{array}$ \\
\hline $\begin{array}{l}\text { Kikuchi et al. }{ }^{18} \\
(2007)\end{array}$ & Transversal & $>70$ years-old & 346 & $\begin{array}{l}\text { Exercising the last } 12 \\
\text { months }\end{array}$ & $\mathrm{ICIQ}^{*}$ & $\uparrow$ exercises $\downarrow$ UI \\
\hline
\end{tabular}

From fully reading 12 articles, 07 were selected. The study aspects are described in -Table 2.

\section{Physical Activity and Urinary Incontinence in Elderly \\ Women}

Kikuchi et al. ${ }^{18}$ assessed the relation between physical activity levels and UI in a population of 346 women over 70 years old. To be able to estimate the incidence of UI, the "International Consultation Incontinence Questionnaire" (ICIQ) was applied. The results show a prevalence of $34 \%$ of women having kidney failure. No correlation was found between high levels of physical activity and reduction of UI. It is presumed that high impact activities (like jogging and tennis), on which you have a significant increase of intra abdominal pressure, can bring over SUI. Moreover, it is concluded that physical activity is effective on primary and secondary control of UI because it reduces the risk of diseases as diabetes, hypertension, obesity and pelvic floor disorders. Moreno-Vecino et al. $^{33}$ compared the relation between physical activity, body composition and UI in 471 women over 65 years old. The UI was evaluated through the "International Consultation Incontinence Questionnaire Short Form" (ICIQ-SF). The physical activity level was evaluated using a set of 08 tests and the fitness index was calculated. Active and sedentary behaviors were then recorded from standardized questionnaires. The UI was found in $28 \%$ of the participants with higher prevalence in obese and lower physical ability ones. There was a trend toward a higher level of physical activity and walking once a day in women with no UI when compared with those with UI.

Danforth et al. ${ }^{34}$ and Morrisroe et al. ${ }^{35}$ evaluated the incidence of UI using the questionnaire which has the following question: "In the last 12 months, how often have you had leakage or loss of urine?," the answer possibilities were: less than once a month, once a month, 2 or 3 times per month, once a week, every day. Women that have the loss more than once a month were defined as incontinence.

Morrisroe et al. $^{35}$ evaluated the fitness performance of Latin women in the United States, applying the Guaralnik Short Physical Performace Battery for more than 60 years. To measure the number of steps they take per day, it was given a pedometer to be used throughout the day. It was shown that physical activity practice is related to lower incidence of UI. The interventions made to improve physical performance may help to prevent UI, as a better functional performance helps the toilet visits, thus keeping a vesical control.

Virtuoso et al. ${ }^{31}$ analyzed the UI incidence and perineal muscle function in 39 elderly women (over 60 years old) active and inactive in regular physical activity. For such they applied the section "Atividade Física de Recreação, Esporte, Exercício e Lazer" from questionnaire "Questionário Internacional de Atividade Física adaptado para idosos", ${ }^{36}$ where 
elderly women were considered as active in case they perform 150 minutes or more of moderate or vigorous physical activity during a regular week. It was included among the activities: aerobics, swimming, dancing, and bodybuilding. They also applied a validated questionnaire ${ }^{37}$ about the urinary tract dysfunctions symptoms and the definition of UI type (stress or urge incontinence) as determined by the International Continence Society (ICS). The participants were inquired making use of a 4 points rating scale (never, sometimes, once a week, all the time or during daytime and nighttime). The pelvic floor function was evaluated by digital palpation using the PERFECT scheme ${ }^{38}$ and perineometry. The results show that physically active elderly women seem to have better pelvic floor function than the inactive ones.

Danforth et al. ${ }^{34}$ evaluated through a questionnaire, the relation between physical activity and the risk to establish UI, in women between 54 and 79 years old. The women were inquired about how much time they spend per week on physical activity, choosing from 0 minutes to 11 hours or more and also indicating which activity was performed among: running, swimming, dancing, aerobics, calisthenic exercises, squash, cycling or low-intensity exercises like yoga (in or outdoor). From the results, they noticed that women that performed walking presented $26 \%$ lower chance of UI compared with the those who performed other activities (aerobics, running, cycling, dancing, water aerobics, among others). There was no evidence of a relation between physical activity and emergency or mixed UI. After prospective investigation they detected that moderate intensity of physical activity, including walking, is associated with $\sim 20-25 \%$ lower chances of developing UI.

\section{Treatment and prevention of $\mathrm{UI}$ in elderly women}

Vinsnes et al. ${ }^{39}$ conducted a randomized clinical trial in 48 women over 65 years old for 3 months, assessing the physical training effect on UI through training in the transfer, overall muscle strength and walking training. Moreover, the group was advised on how to execute daily activities, primarily how to carry weight and decubitus positioning since the group consisted of home care nurses. The control group had 50 women. The evaluation method to measure urinary loss before and after the intervention was the 24-hour pad test. The results showed that urinary loss was significantly lower in the group under intervention.

Tak et al. ${ }^{43}$ conducted a multicentric randomized clinical trial with 192 institutionalized women with an average of 84 years old, divided into two groups: intervention $(n=102)$ and control $(n=90)$. The selected women must have good cognitive and physical function to participate in a program that included instructions on behavioral aspects of continence, exercises to improve pelvic floor muscles, bladder, and physical performance. The program included weekly group training for 30 minutes each, to improve the functional ability to use the toilet in an independent manner. The exercises included: sitting and getting up from chair and bed, upper- limb mobility and walking. The intervention was performed by a physiotherapist specialized in pelvic floor musculature training, with experience in group training and affinity with the elderly. The Physical Performance Test (PPT) was applied. The involuntary urine loss was measured through the three- day voiding diary. The reduction of UI was noticed in $40 \%$ of the intervention group and in only $28 \%$ of the control group. The frequency of urine loss episodes decreased in both groups in six months (51\% in the intervention group and $42 \%$ in the control group). The physical performance improved in the intervention group and worsened in the control group during the study. The physical performance improvement was related to joining in an exercise program.

\section{Discussion}

The physical activity is an integral part of promoting healthy, active and independent aging, and urinary complaints cannot be neglected, as it is established that women can quit exercising if they experience urinary losses during the exercises, directly affecting their physical fitness and functional performance. ${ }^{40,41}$

Individual strategies and training for UI control should be embraced and not allow this symptom to be part of the women aging process since UI is one of the major public health problems in aging, affecting negatively the life quality of this population. ${ }^{18}$ The UI during physical activity is an obstacle that can hinder people from exercising, mainly in women with more severe losses, increasing the possibility of inactivity and obesity. ${ }^{42}$

The urine loss issue in young female athletes has been underestimated. Several studies show increased risk of UI in this population and tends to be even worse over the years. ${ }^{43}$ Approximately $30 \%$ of female athletes experience some urinary loss during exercise. ${ }^{44}$ Young women who practice low-intensity exercise for at least 1 hour or more per week, have less UI compared with the group of sedentary women. ${ }^{45}$ However, studies that show correlation of UI and physical activity in elderly women are limited, some studies include in its research only physical activity practice, ${ }^{31,34}$ and some include an association between daily activities orientations and physical activity (Vinsnes et al., 2012; Morrisroe et al., 2014). Elderly women who practice low/moderate physical activity have lower UI complaints when compared with sedentary women. ${ }^{34}$ 25,33,49 Danforth et al. found a decrease in UI risk of 20 - 25\% in elderly women who walk, as well as active young women also have a lower incidence of UI. ${ }^{46}$

Sedentary women should be advised to participate in a low or moderate physical activity program. The exercise program should be unconditionally embraced to prevent or reduce urinary losses and enhance physical. ${ }^{35,44}$

The pelvic floor muscle exercising, when performed with the help of a qualified physiotherapist, is an important factor both for the prevention and for the UI treatment, and it is the first line therapy in women with UI. ${ }^{32,47}$ The exercises for the pelvic floor muscles when associated with the regular physical activity contribute effectively to UI reduction and should be embraced into physical activity practice. $^{44,48}$ 
Physically active women have a stronger pelvic floor. The women who participated in a low-intensity exercise program for one hour or more per week had fewer UI complaints compared with the nonparticipating group. ${ }^{45}$ On the other hand, some high impact activities may increase SUI symptoms during exercise. Therefore, it is recommended for this population to practice low or moderate intensity exercises and it is advised to contract the pelvic floor muscles in every situation of intra abdominal pressure increasing. ${ }^{31}$ Nygaard and Shaw ${ }^{46}$ suggest that women with some loss during exercise, carry out prevention strategies such as emptying the bladder before activity. No association between physical activity and UI is established, there is still the hypothesis that women with some loss should avoid physical activity. ${ }^{35}$

Nygaard et al. $^{42}$ assessed the prevalence of UI in middleaged women (from 39 to 65 years old) and concluded that intense physical activity performed for more than 10 years may be associated with a moderate increase in SUI. Thus, walking is an effective modality to be practiced by elderly women to promote functional performance improvement, it has no negative effects on UI and helps the overweight control and obesity ${ }^{33,41}$ since weight reduction is associated with UI reduction. 49

Hannestad et $\mathrm{al}^{45}$ found that the risk of severe incontinence among obese women was three times higher than in normal weight women. Low or moderate physical activity helps maintain the body weight, reduces body fat, decreases intra abdominal pressure, and strengthens the pelvic floor. ${ }^{33}$ There is, therefore, the hypothesis that women that practices physical exercises have a lower body mass index, which may also contribute to the lower incidence of UI complaints.

The multimorbidity contributes to a sedentary lifestyle and inactivity, so health programs should include changes in women's lifestyles. These changes should include weight loss, control of chronic diseases, maintenance of mobility and functional capacity, and restoration of life quality. ${ }^{50}$ Morrisroe et al. $^{35}$ found that the decline in health, obesity and low physical performance is associated with a higher incidence of UI, and they associated the best physical performance to the ability to easily move to the bathroom, reducing urinary losses.

This study has faced some limitations. The first was the lack of clinical trials proving that elderly women that practice physical activity has a lower incidence of UI. Therefore, in most of the studies, questionnaires were sent to assess the extent of the UI and which physical activity they perform. Future studies should be conducted on elderly women population to conclude which activity is most effective in preventing and controlling UI.

\section{Conclusion}

The data indicate that elderly older women who participate in regular exercise programs have a lower incidence of UI. Therefore, it is necessary to endorse physical activity for the studied population.

\section{References}

1 Silva MFD, Goulart NBA, Lanferdini FJ, Marcon M. DIAS C.P. Relação entre os níveis de atividade física e qualidade de vida de idosos sedentários e fisicamente ativos. Rev Bras Geriatr Gerontol 2012;15 (04):634-642. Doi: 10.1590/S1809-98232012000400004

2 World Health Organization - WHO. Global recommendations on physical activity for health. Geneva: WHO; 2010

3 Ciolac EG. Exercise training as a preventive tool for age-related disorders: a brief review. Clinics (Sao Paulo) 2013;68(05): 710-717. Doi: 10.6061/clinics/2013(05)20

4 Abrams P, Cardozo L, Fall M, et al; Standardisation Sub-committee of the International Continence Society. The standardisation of terminology of lower urinary tract function: report from the Standardisation Sub-committee of the International Continence Society. Neurourol Urodyn 2002;21(02):167-178. Doi: 10.1002/ nau. 10052

5 Fantl JA, Cardozo L, McClish DK. Estrogen therapy in the management of urinary incontinence in postmenopausal women: a meta-analysis. First report of the Hormones and Urogenital Therapy Committee. Obstet Gynecol 1994;83(01):12-18

6 Rett MT, Simões JA, Herrmann V, Gurgel MSC, Morais SS. Qualidade de vida em mulheres após tratamento da incontinência urinária de esforço com fisioterapia. Rev Bras Ginecol Obstet 2007;29(03): 134-140. Doi: 10.1590/S0100-72032007000300004

7 DeLancey JO. Structural aspects of the extrinsic continence mechanism. Obstet Gynecol 1988;72(3 Pt 1):296-301

8 Stolzenburg JU, Dorschner W, Postenjak M, et al. Sphincteric musculature of female canine urethra in comparison to woman including 3D reconstruction. Cells Tissues Organs 2002;170 (2-3):151-161

9 Andersson KE, Arner A. Urinary bladder contraction and relaxation: physiology and pathophysiology. Physiol Rev 2004;84(03): 935-986. Doi: 10.1152/ physrev.00038.2003

10 Junqueira LC, Carneiro J. Histologia básica: texto e atlas. 12. ed. Rio de Janeiro: Guanabara. Koogan; 2013

11 Hicks RM. The mammalian urinary bladder: an accommodating organ. Biol Rev Camb Philos Soc 1975;50(02):215-246

12 Egeblad M, Werb Z. New functions for the matrix metalloproteinases in cancer progression. Nat Rev Cancer 2002;2(03):161-174. Doi: $10.1038 / \mathrm{nrc745}$

13 Kaya C, Şahin B. The role of extracellular matrix proteins in the urinary tract: a literature review. In: F. Travascio. Biochemistry, genetics and molecular biology. composition and function of the extracellular matrix in the human body, 2015

14 Aitken KJ, Bägli DJ. The bladder extracellular matrix. Part I: architecture, development and disease. Nat Rev Urol 2009;6 (11):596-611. Doi: 10.1038/ nrurol.2009.201

15 Kim BS, Baez CE, Atala A. Biomaterials for tissue engineering. World J Urol 2000;18(01):2-9. Doi: 10.1007/s003450050002

16 Reisdoerfer G, Pereira KF, Chopard RP. Efeitos do envelhecimento sobre os componentes fibroelásticos da junção vésicouretral: uma breve revisão. Arq Ciênc Saúde UNIPAR 2009;13(03):255-262

17 Bresee C, Dubina ED, Khan AA, et al. Prevalence and correlates of urinary incontinence among older community-dwelling women. Female Pelvic Med Reconstr Surg 2014;20(06):328-333. Doi: 10.1097/SPV.0000000000000093

18 Kikuchi A, Niu K, Ikeda Y, et al. Association between physical activity and urinary incontinence in a community-based elderly population aged 70 years and over. Eur Urol 2007;52(03): 868-874

19 Milsom I, Ekelund P, Molander U, Arvidsson L, Areskoug B. The influence of age, parity, oral contraception, hysterectomy and menopause on the prevalence of urinary incontinence in women. J Urol 1993;149(06):1459-1462

20 Zhao W, Aboushwareb T, Turner C, et al. Impaired bladder function in aging male rats. J Urol 2010;184(01):378-385. Doi: 10.1016/j.juro.2010.03.004 
21 Kitta T, Yoshikawa S, Kawamorita N, de Groat WC, Nonomura K, Yoshimura N. The effect of ovariectomy on urethral continence mechanisms during sneeze reflex in middle-aged versus young adult rats. Neurourol Urodyn 2016;35(01):122-127. Doi: 10.1002/ nau. 22690

22 Lluel P, Palea S, Barras M, et al. Functional and morphological modifications of the urinary bladder in aging female rats. Am J Physiol Regul Integr Comp Physiol 2000;278(04):R964-R972

23 Strasser H, Tiefenthaler M, Steinlechner M, Bartsch G, Konwalinka G. Urinary incontinence in the elderly and age-dependent apoptosis of rhabdosphincter cells. Lancet 1999;354(9182):918-919. Doi: 10.1016/ S0140-6736(99)02588-X

24 Trutnovsky G, Guzman-Rojas R, Martin A, Dietz HP. Pelvic floor dysfunction-does menopause duration matter? Maturitas 2013; 76(02):134-138. Doi: 10.1016/j.maturitas.2013.06.012

25 Tzur T, Yohai D, Weintraub AY. The role of local estrogen therapy in the management of pelvic floor disorders. Climacteric 2016;19(02): 162-171http://dx.doi.org/10.31 09/13697137.2015.1132199

26 Herschorn S. Female pelvic floor anatomy: the pelvic floor, supporting structures, and pelvic organs. Rev Urol 2004;6(05, Suppl 5):S2-S10

27 Ashton-Miller JA, Howard D, DeLancey JO. The functional anatomy of the female pelvic floor and stress continence control system. Scand J Urol Nephrol Suppl 2001;207(207):1-7, discussion 106-125. Doi: 10.1080/003655901750174773

28 Thelen DG, Ashton-Miller JA, Schultz AB, Alexander NB. Do neural factors underlie age differences in rapid ankle torque development? J Am Geriatr Soc 1996;44(07):804-808. Doi: 10.1111/ j.1532-5415.1996.tb03737.x

29 Alperin M, Cook M, Tuttle LJ, Esparza MC, Lieber RL. Impact of vaginal parity and aging on the architectural design of pelvic floor muscles. Am J Obstet Gynecol 2016;215(03):312.e1-312.e9. Doi: 10.1016/j.ajog.2016.02.033

30 Bocardi DAS, Baldon VP, Driusso P. Influência do envelhecimento sobre a função e atividade eletromiográfica dos músculos do assoalho pélvico de mulheres nuligestas. Revista Univap 2017;22 (40):567

31 Virtuoso JF, Mazo GZ, Menezes EC. Incontinência urinária e função muscular perineal em idosas praticantes e não-praticantes de atividade física regular. Braz J Phys Ther 2011;15(04):310-317. Doi: 10.1590/ S1413-35552011005000014

$32 \mathrm{~B} ø \mathrm{~K}$, Herbert RD. There is not yet strong evidence that exercise regimens other than pelvic floor muscle training can reduce stress urinary incontinence in women: a systematic review. J Physiother 2013;59(03):159-168. Doi: 10.1016/S1836-9553(13)70180-2

33 Moreno-Vecino B, Arija-Blázquez A, Pedrero-Chamizo R, et al; EXERNET Group. Associations between obesity, physical fitness, and urinary incontinence in non-institutionalized postmenopausal women: The elderly EXERNET multi-center study. Maturitas 2015;82(02):208-214. Doi: 10.1016/j.maturitas.2015.07.008

34 Danforth KN, Shah AD, Townsend MK, et al. Physical activity and urinary incontinence among healthy, older women. Obstet Gynecol 2007;109(03):721-727. Doi: 10.1097/01.AOG.0000255973.92450.24

35 Morrisroe SN, Rodrigues LV, Wang PC, Smith AL, Trejo L, Sarkisian CA. Correlates of 1-year incidence of urinary incontinence in Latino adults enrolled in a community-based physical activity trial. J Am Geriatr Soc 2014;62(04):740-746. Doi: 10.1111/jgs.12729
36 Benedetti TB, Mazo GZ, Barros MVG. Aplicação do Questionário Internacional de Atividades Físicas para avaliação do nível de atividades físicas de mulheres idosas: validade concorrente e reprodutibilidade teste-reteste. Revista Brasileira de Ciência e Movimento 2004;12(01):25-34

37 Jackson S, Donovan J, Brookes S, Eckford S, Swithinbank L, Abrams P. The Bristol Female Lower Urinary Tract Symptoms questionnaire: development and psychometric testing. Br J Urol 1996;77 (06):805-812. Doi: 10.1046/j.1464-410X.1996.00186.x

38 Laycock J, Jerwood D. Pelvic floor muscle assessment: the PERFECT scheme. Physiotherapy 2001;87(12):631-642. Doi: 10.1016/S00319406(05)61108-X

39 Vinsnes AG, Helbostad JL, Nyrønning S, Harkless GE, Granbo R, Seim A. Effect of physical training on urinary incontinence: a randomized parallel group trial in nursing homes. Clin Interv Aging 2012;7:45-50. Doi: 10.2147/CIA.S25326

40 Caetano AS, Gomes C, Fernandes C, Helena M, De Moraes B. Urinary incontinence and physical activity practice. Rev Bras Med Esporte 2007;13(09):245-248

41 Moller L, Lose G, Jorgensen T. Risk factors for lower urinary tract symptoms in women aged 40-60 years Risk Factors for Lower Urinary Tract Symptoms in Women 40 to 60 Years of Age. Obstet Gynecol 2016;96(03):446-451. Doi: 10.1097/00006250-200009000-00022

42 Nygaard I, Girts T, Fultz NH, Kinchen K, Pohl G, Sternfeld B. Is urinary incontinence a barrier to exercise in women? Obstet Gynecol 2005; 106(02):307-314. Doi: 10.1097/01.AOG.0000168455.39156.0f

43 Meczekalski B, Katulski K, Czyzyk A, Podfigurna-Stopa A. Health in older women athletes. Maturitas 2014;79(04):357-361

44 Goldstick O, Constantini N. Urinary incontinence in physically active women and female athletes. Br J Sports Med 2014;48(04): 296-298

45 Hannestad YS, Rortveit G, Daltveit AK, Hunskaar S. Are smoking and other lifestyle factors associated with female urinary incontinence? The Norwegian EPINCONT Study. BJOG 2003;110(03): 247-254. Doi: 10.1046/j.1471- 0528.2003.02327.x

46 Nygaard IE, Shaw JM. Physical activity and the pelvic floor. Am JObstet Gynecol 2016;214(02):164-171. Doi: 10.1016/j.ajog.2015.08.067

47 Dumoulin C, Hay-Smith EJC, Mac Habée-Séguin G. Pelvic floor muscle training versus no treatment, or inactive control treatments, for urinary incontinence in women. Cochrane Libr $2014 ; \cdots \cdot 5$

48 Tak ECPM, van Hespen A, van Dommelen P, Hopman-Rock M. Does improved functional performance help to reduce urinary incontinence in institutionalized older women? A multicenter randomized clinical trial. BMC Geriatr 2012;12(51):51

49 Imamura M, Williams K, Wells M and MCGROTHER, C. Lifestyle interventions for the treatment of urinary incontinence in adults. Cochrane Database Syst Rev 2015;12:12-15

50 Reigota RB, Pedro AO, de Souza Santos Machado V, Costa-Paiva L, Pinto-Neto AM. Prevalence of urinary incontinence and its association with multimorbidity in women aged 50 years or older: A population-based study. Neurourol Urodyn 2016;35(01):62-68. Doi: 10.1002/nau.22679

51 Townsend MK, Curhan GC, Resnick NM, Grodstein F. BMI, waist circumference, and incident urinary incontinence in older women. Obesity (Silver Spring) 2008;16(04):881-886. Doi: 10.1038/oby.2008.14 